\title{
Serum Nerve Growth Factor, Interleukin-13 and Tumor Necrosis Factor - A in patients with Systemic Lupus Erythematosus
}

\author{
Magdy A. Al Tahhan*, Mervat A. El-Toukhy** \\ and Ehab M. Salem *** \\ Medical Biochemistry*, Rheumatology \& Rehabilitation** and Internal \\ Medicine*** Departments, Faculty of Medicine, Zagazig University
}

\begin{abstract}
systemic lupus erythematosus(SLE) is an autoimmune disease characterized by B-cell hyperactivity, production of autoantibody and abnormal immunoregulation. At present, both interleukin-13(IL-13) and nerve growth factor(NGF) have been proved to play a role in stimulating the proliferation and differentiation of human B-cells and inducing immunoglobulin(Ig) synthesis.Tumor necrosis factor-a(TNF-a) is both a proinflammatory and immunomodulatory cytokine. It was suggested to affect NGF expression. Therefore, the present study was designed to determine serum NFG, IL-13 and TNF- $\alpha$ in 31 patients with systemic lupus erythematosus (SLE) and to assess their relationship with the disease activity as measured by SLE Disease Activity Index (SLEDAI). The results showed that the levels of serum NGF $(308 \pm 85 \mathrm{pg} / \mathrm{ml}), I L-$ $13(92.69 \pm 9.87 \mathrm{pg} / \mathrm{ml})$ and TNF-a $(50.6 \pm 11.3 \mathrm{pg} / \mathrm{ml})$ in active SLE patients were significantly higher than those in inactive SLE patients (NGF, $244 \pm 76 \mathrm{pg} / \mathrm{ml} ; \mathrm{IL}-13$, $54.22 \pm 9.31 \mathrm{pg} / \mathrm{ml} ; T N F-a, 29.4 \pm 9.8 \mathrm{pg} / \mathrm{ml})(\mathrm{p}<0.01$. The inactive patients also had significantly increased serum levels of NGF, IL-13 and TNF-a as compared with normal controls( NGF,72.29 $23.6 \mathrm{pg} / \mathrm{ml} ; \mathrm{IL}-13,35.20 \pm 12.70 \mathrm{pg} / \mathrm{ml} ; \mathrm{TNF}-a, 8.7 \pm 3.0$ $\mathrm{pg} / \mathrm{ml})(\mathrm{p}<0.001)$. Spearman correlation analysis revealed that the serum levels of NGF,IL-13 and TNF-a were correlated with disease activity index of SLE(SLEDAI),ESR and serum levels of C3 and C4(NGF, $r=0.442,-0.41,-0.38$; $I L-13, r=0.813,-0.504,-0.605 ; T N F-a, r=0.69,-0.43,-0.52$ respectively). The serum levels of NGF, IL-13 and TNF-a had a positive correlation ( $r=0.506, p<0.01)$. Significant positive correlations were observed between NGF, TNF-a and SLEDAI. Also, a significant positive correlation was present between TNF-a and NGF suggesting that elevated TNF-a levels may lead to a continued increase of NGF production. In conclusion, the present results suggest that $N G F, I L-13$ and TNF- $\alpha$ may play a role in the pathogenesis of SLE and closely correlated with the disease activity, therefore they could be used as sensitive markers for evaluating the disease activity.
\end{abstract}

Key Words: $N G F, I L-13$ and, TNF- $\mathbf{\alpha}$, systemic lupus erythematosus. 


\section{INTRODUCTION}

SLE is a chronic autoimmune disease characterized by the deposition of immune complexes in different organs. The etiology of SLE is unknown, many predisposing factors playing an important role have been found, including genetic, environmental, infectious, and hormonal factors ${ }^{(1)}$. In SLE, B cell hyperactivity and the presence of multiple autoantibodies were observed together with abnormalities in the Tcell immune response ${ }^{(2)}$. In addition, numerous abnormalities of the cytokine network have been described in patients suffering from SLE, some of them were shown to play a pivotal pathophysiological role in certain $\mathrm{T}$ cell, B cell or antigen-presenting cell dysfunctions characteristic of the disease $^{(3)}$. Of these cytokines, nerve growth factor (NGF) has emerged as Th2 cytokine with an immunomodulatory effects ${ }^{(4)}$. NGF is the best-characterized member of neurotrophin family which include the brain-derived neurotrophic factor, neurotrophin-3 (NT-3) and neurotrophin-4 (NT-4) ${ }^{(5)}$. NGF through a specific tyrosine kinase receptor (TrKA) and a receptor belong to the TNF- $\alpha$ family promotes differentiation, growth and survival of peripheral and central neurons ${ }^{(6)}$. NGF receptors are expressed by several immune cells, suggesting the potential of responding to that neurotrophin $^{(7)}$. There are extensive evidences that NGF is involved in the development and differentiation of immune cells. It enhances lymphocytes proliferation in both $\mathrm{B}$ and $\mathrm{T}$ cell population and it stimulates the production of $\operatorname{IgM}$, IgA and $\operatorname{IgG}^{(\mathbf{8})}$. Also, NGF is capable to induce high affinity IL - 2 receptors on human peripheral blood mononuclear cells ${ }^{(\mathbf{9})}$. In addition to a variety of NGF effects on immune system, several cells such as mast cells, lymphocytes and eosinophils produce, store and release $\mathrm{NGF}^{(4)}$. The expression of NGF is up-regulated in different inflammatory processes and in a variety of autoimmune diseases such as rheumatoid $\operatorname{arthritis}^{(\mathbf{1 0})}$, progressive systemic sclerosis ${ }^{(11)}$, children with $\mathrm{SLE}^{(\mathbf{1 2})}$ and autoimmune thyroid disease ${ }^{(\mathbf{1 3})}$. Different cytokines such as TNF-a, interleukin-10 and Thl cytokines (IL-2 and interferon-y) were suggested to affect NGF expression $^{(14)}$.

IL-13, a sort of Th2 cytokine cloned recently, is mainly produced by activated $\mathrm{T}$-cells ${ }^{(15)}$. It can stimulate B-cell proliferation and activation and induce Ig secretion, and plays an important role in humoral immune response. TNF- $\alpha$ is a proinflammatory cytokine which is produced primarily by activated monocytes/ macrophages, activated $\mathrm{T}$ cells, B cells, mast cells, endothelial cells and fibroblasts. It has different effects on immune cells. It is a growth factor for B lymphocytes ${ }^{(\mathbf{1 6})}$ and also constitutes an activation and maturation factor of dendritic cells which are essential in immune regulation $^{(17)}$. The implication of TNF- $\alpha$ as a principal player in several inflammatory and autoimmune diseases led to the potential effectiveness of TNF- $\alpha$ blocking agents in the biological treatment of 
such diseases as psoriasis and rheumatoid arthritis ${ }^{(\mathbf{1 8 )}}$. The current study aimed to assess serum levels of NGF, IL-13 and TNF- $\alpha$ in Egyptian patients with SLE and to correlate their levels with the disease activity using SLE Disease Activity Index (SLEDAI).

\section{SUBJECTS \& METHODS}

Study population: Thirty one patients with SLE (26 females and 5 males) were selected from the Inpatient and Outpatient Clinics of Rheumatology \& Rehabilitation and Internal Medicine Departments, Zagazig Faculty of Medicine. They were diagnosed according to the American College of Rheumatology criteria for classification of SLE ${ }^{(19)}$. Seventeen healthy subjects (15 females and 2 males) unrelated to the patients without inflammatory or autoimmune disease, matched to age and gender of the patients, were included as controls. The characteristics of all subjects were shown in table 1.

All patients were under steroid therapy alone or in combination with immunosuppressive agents. The steroid dose was $0.5-1 \mathrm{mg} / \mathrm{kg} /$ day (oral) and 10-20 mg/kg/ 1-3 successive days of methyl prednisolone I.V (for lupus nephritis patients). The immunosuppressive agents dose was Azathioprine 2.5 $\mathrm{mg} / \mathrm{kg} /$ day and pulsed cyclophosphamide $0.5-1 \mathrm{~g} / \mathrm{m}$ surface area monthly for 6 months, then every 3 months for 2 years (for patients with lupus nephritis).

At the time of blood withdrawing, the clinical presentation of SLE patients was, 28 patients (91\%) suffered from active skin affection, 15 (48\%) from renal affection, $11(35 \%)$ from CNS involvement, 15 (48\%) from musculoskeletal system affection, $9 \quad$ (29\%) from cardiopulmonary symptoms and 20 (64\%) with leucopenia and thrombocytopenia.

Methods:

All subjects were subjected to the following:

I- Thorough clinical examination including history taking with special enquiry about the presence of fever, arthritis, headache or new rashes.

II- Disease activity assessment was evaluated according to SLEDAI as described by Bombardier et al. ${ }^{(20)}$. It includes 24 items for 9 organs, scored (present or absent) in the last 10 days. SLE patient with SLEDAI score $\geq 10$ were considered in a state of active disease. Accordingly, seventeen SLE patients with SLEDAI $\geq 10$ served as , active group, while the remainder 14 SLE patients with SLEDAI $<10$ served as inactive group.

III- Routine laboratory tests:

- Urine analysis for the presence of cellular casts, hematuria, pyuria, and protein in 24 hours urine.

- Complete blood picture.

- ESR.

- Serum creatinine.

- Anti-ds DNA was determined by indirect immunoflourescent technique according to Peter and Dawkins ${ }^{(21)}$. 
IV- Measurement of complement C3 and $\mathrm{C} 4$ by immunochemical method as described by Hebert et al. ${ }^{(22)}$ using BN Prospic analyzer (Bade, Behring Inc. Marhurg $\mathrm{GmbH})$.

V- Cytokines measurements:

- Serum NGF was estimated by ELISA technique according to Hellweg et al.. ${ }^{(23)}$ using kits provided by Roche Diagnostics $\mathrm{GmbH}$, Mannheim, Germany.

- The levels of serum IL-13 were determined by Sandwich ELISA according to $\mathrm{Xu}$ and $\mathrm{Chen}^{(24)}$ following the instruction of ELISA kits (Shanghai Senxiong Technology Co., Ltd. )

- Serum TNF- $\alpha$ was measured by sandwich enzyme-linked Immunosorbent assay according to Cannon et al. ${ }^{\text {(25) }}$ using commercial kit (Bio Source Europe S.A. Belgium).

\section{Statistical Analysis:}

The results are presented as mean \pm standard deviation (SD). Student ttest and Pearson's test were used for analysis of data. In all cases, $\mathrm{P}<0.05$ was considered significant. Results were analyzed with Epi-info version 6.02 computer package.

\section{RESULTS}

- Serum NGF: Significant increase $(\mathrm{P}<0.001)$ in serum NGF was present in all SLE patients as compared with the control group (Table 2). Patients with active SLE showed significant increase $(\mathrm{P}<$ 0.001 ) in serum NGF as compared with patients with inactive disease (table 3).

- Serum IL-13 : Significant increase $(\mathrm{P}<0.001)$ in serum IL-13 was observed in all SLE patients as compared with the control groups (Table 2). Patients with active SLE showed significant increase $(\mathrm{P}<0.001)$ in IL-13 as compared with patients with inactive disease (table 3).

- Serum TNF- $\alpha$ : Significant increase $(\mathrm{P}<0.001)$ in serum TNF- $\alpha$ was observed in all SLE patients as compared with the control groups (Table 2), while patients with active SLE showed significant increase $(\mathrm{P}<0.001)$ in $\mathrm{TNF}-\mathrm{a}$ as compared with patients with inactive disease (table 3).

Cytokine levels and disease activity: Significant positive correlations were observed between serum NGF, IL-13 and TNF- $\alpha$ on one hand and SLEDAI on the other hand $(\mathrm{r}=0.51$, $\mathrm{P}<0.01),(\mathrm{r}=0.83, \mathrm{P}<0.001)$ and $(\mathrm{r}=$ 0.77, PO.01) respectively.

Cytokine levels and some laboratory findings: Positive correlations were observed between NGF, TNF- $\alpha$ and ESR, while significant negative correlations were observed between them and $\mathrm{C}_{3}, C_{4}$. 
Table (1): Clinical data, $C_{3}$ and $C_{4}$ levels of controls and SLE patients.

\begin{tabular}{llll}
\hline & Control group & Inactive group & Active group \\
\hline Age $(\mathrm{yr}), \quad($ mean $\pm \mathrm{SD})$ & $27.6 \pm 7.9$ & $26.8 \pm 6.5$ & $28.3 \pm 9.2$ \\
\hline Sex $(\mathrm{F} / \mathrm{M})$ & $17(15 / 2)$ & $14(12 / 2)$ & $17(14 / 3)$ \\
\hline Duration of disease $($ months $)$, & - & $35.6 \pm 16.33$ & $36.4 \pm 17$ \\
\hline SLEDAI,$(\mathrm{mean} \pm \mathrm{SD})$ & - & $6.7 \pm .7$ & $22.1 \pm 6.9$ \\
\hline Serum $\mathrm{C}_{3}(\mathrm{mg} / \mathrm{dl}),(\mathrm{mean} \pm \mathrm{SD})$ & $67 \pm 17.5$ & $48.6 \pm 7.3^{*}$ & $34 \pm 8.6^{*}$ \\
\hline Serum $\mathrm{C}_{4}(\mathrm{mg} / \mathrm{dl}),($ mean $\pm \mathrm{SD})$ & $31.6 \pm 5.9$ & $25 \pm 4.8^{*}$ & $20 \pm 4.6^{*}$ \\
\hline & &
\end{tabular}

* Significant

Table (2): Serum levels of NGF and TNF- $\alpha$ in SLE patients and control group $($ mean \pm SD)

\begin{tabular}{llll}
\hline & Control group & SLE & P \\
\hline Serum NGF $(\mathrm{pg} / \mathrm{ml})$ & $72.29 \pm 23.6$ & $279 \pm 86$ & $<0.001^{*}$ \\
\hline Serum IL-13 $(\mathrm{pg} / \mathrm{ml})$ & $35.20 \pm 12.70$ & $67.34 \pm 9.31$ & $<0.001^{*}$ \\
\hline Serum TNF- $\alpha(\mathrm{pg} / \mathrm{ml})$ & $8.7 \pm 3$ & $41 \pm 15$ & $<0.001^{*}$ \\
\hline
\end{tabular}

* Significant

Table (3): Serum levels of NGF, IL-13 and TNF- $\alpha, C_{3}, C_{4}$ and ESR in active and inactive SLE patients (Mean \pm SD).

\begin{tabular}{llll}
\hline & Inactive group & Active group & P \\
\hline Serum NGF $(\mathrm{pg} / \mathrm{ml})$ & $244 \pm 76$ & $308 \pm 85$ & $<0.001^{*}$ \\
\hline Serum IL-13 $(\mathrm{pg} / \mathrm{ml})$ & $54.22 \pm 9.31$ & $92.69 \pm 9.87$ & $<0.001^{*}$ \\
\hline Serum TNF- $\alpha(\mathrm{pg} / \mathrm{ml})$ & $29.4 \pm 9.8$ & $50.6 \pm 11.3$ & $<0.001^{*}$ \\
\hline Serum C $(\mathrm{mg} / \mathrm{dl})$ & $48.6 \pm 7.3$ & $34 \pm 8.6$ & $<0.01^{*}$ \\
\hline Serum $C_{4}(\mathrm{mg} / \mathrm{dl})$ & $25 \pm 8.4$ & $20 \pm 4.6$ & $<0.05^{*}$ \\
\hline $\begin{array}{c}\text { ESR 1 } \\
2^{\text {nt }} \text { hour }(\mathrm{mm})\end{array}$ & $61.0 \pm 13.0$ & $94 \pm 9.8$ & $<0.001^{*}<0.001^{*}$ \\
\hline
\end{tabular}

\footnotetext{
* Significant
} 
Table (4): Correlations between serum NGF and other variables in the SLE patients $(\mathbf{n}=\mathbf{3 1})$.

\begin{tabular}{lll}
\hline & $\mathbf{r}$ & $\mathbf{P}$ \\
\hline SLEDAI & 0.51 & $<0.01^{*}$ \\
\hline Duration of disease & 0.28 & $>0.05$ \\
\hline ESR & 0.43 & $<0.05^{*}$ \\
\hline $\mathrm{C}_{3}$ & -0.41 & $<0.05^{*}$ \\
\hline $\mathrm{C}_{4}$ & -0.38 & $<0.05^{*}$ \\
\hline TNF- $\alpha$ & 0.39 & $<0.05^{*}$ \\
\hline IL-13 & 0.34 & $<0.05^{*}$ \\
\hline
\end{tabular}

* Significant

Table (5): Correlations between serum IL-13 and other variables in the SLE patients $(\mathbf{n}=\mathbf{3 1})$.

\begin{tabular}{lll}
\hline \multicolumn{1}{c}{$\mathbf{r}$} & \multicolumn{1}{c}{$\mathbf{p}$} \\
\hline SLEDAI & 0.813 & $<0.001^{*}$ \\
\hline Duration of disease & 0.24 & $>0.05$ \\
\hline ESR & 0.504 & $<0.002^{*}$ \\
\hline $\mathrm{C}_{3}$ & -0.605 & $<0.001^{*}$ \\
\hline $\mathrm{C}_{4}$ & -0.463 & $<0.005^{*}$ \\
\hline TNF- $\alpha$ & 0.39 & $<0.05^{*}$ \\
\hline IL-13 & 0.36 & $<0.05^{*}$ \\
\hline
\end{tabular}

* Significant

Table (6): Correlations between serum TNF-a and other variables in the SLE patients $(\mathbf{n}=\mathbf{3 1})$.

\begin{tabular}{lll}
\hline & $\mathbf{r}$ & $\mathbf{p}$ \\
\hline SLEDAI & 0.77 & $<0.001^{*}$ \\
\hline Duration of disease & 0.19 & $>0.05$ \\
\hline ESR & 0.69 & $<0.001^{*}$ \\
\hline $\mathrm{C}_{3}$ & -0.43 & $<0.05^{*}$ \\
\hline $\mathrm{C}_{4}$ & -0.52 & $<0.001^{*}$ \\
\hline NGF & 0.39 & $<0.05^{*}$ \\
\hline IL-13 & 0.37 & $<0.05^{*}$ \\
\hline
\end{tabular}

\footnotetext{
* Significant
} 


\section{DISCUSSION}

SLE is an autoimmune disease with a clear imbalance in the network of different cytokines ${ }^{(26)}$. The role of cytokines in the pathogenesis of SLE as well as the effect of cytokine blockade is still controversial.

$N G F$ is considered as one of Th2 cytokines suggested to be involved in the pathophysiology of SLE through its immunomodulatory effects on different cells of immune system. NGF enhances lymphocyte proliferation in both $\mathrm{B}$ and $\mathrm{T}$ cell population and stimulates the production of $\operatorname{IgM}, \operatorname{IgG}$, and $\operatorname{IgA}{ }^{(9)}$. Also, NGF has been found to be an autocrine survival factor for memory B cell ${ }^{(27)}$. The role played by NGF on cells of the immune system was strengthened by evidence demonstrating that cells normally present in inflammatory tissues such as mast cells, lymphocytes, express NGF receptors and are receptive to its action in an autocrine manner ${ }^{(28)}$.

In the present study, the level of NGF was significantly higher in SLE patients compared with the controls. Furthermore, it was, also, significantly higher in SLE group with active disease compared to SLE group with inactive disease. These results are in line with the earlier finding showing increased levels of NGF in SLE patients by Dicou et al. ${ }^{(29)}$ and in other autoimmune disease such as multiple sclerosis ${ }^{(\mathbf{3 0})}$, Hashimoto's thyroiditis $^{(31)}$ as well as in other brain disorders with autoimmune etiology ${ }^{(32)}$.

Previous studies have shown that NGF is produced by various
Immune cells ${ }^{(33)}$, which also express TrKA receptors, mediating the action of $\mathrm{NGF}^{(34)}$. The observation that the concentration of NGF is enhanced in the autoimmune disease, along with the evidence that cells of immune system are able to respond to and/or synthesize NGF has led to the hypothesis that NGF might be involved in autoimmune disease.

The results of the present study revealed that NGF was correlated significantly with SLEDAI indicating that NGF measurements could be a useful marker for the evaluation of the activity of the disease. At the same time, significant positive correlation was observed between serum NGF and ESR. On the other hand, significant negative correlation was present between $\mathrm{NGF}$ and serum levels of $\mathrm{C}_{3}$ and $\mathrm{C}_{4}$. These observations are in agreement with those of $\mathrm{Xu}$ and Chen ${ }^{(24)}$ who found that NGF levels were elevated in SLE patients with active disease as compared to patients with inactive disease and, also, they found significant correlations between serum $\mathrm{NGF}$ and SLEDAI ESR, serum $\mathrm{C}_{3}$ so they suggested that NGF might be involved in the pathogenesis of SLE and closely correlated with disease activity .The source of elevated NGF in SLE is not clear, but many immune cells, activated in SLE, have the capacity to synthesize and release NGF. Thus, it seems likely that immune processes could be a source for NGF production. Moreover, proinflammatory cytokines such as TNF- $\alpha$ stimulates NGF production ${ }^{(35)}$.

In the current study, elevated levels of TNF- $\alpha$ were present in SLE 
patients and significant positive correlation was observed between its levels and the levels of serum NGF suggesting that elevated TNF- $\alpha$ levels may lead to a continued increase of NGF production. That finding confirms the earlier results of the experimental study of Bennett et al. (36) who found that the synovium of transgenic arthritic mice overexpressing TNF- $\alpha$ contains high levels of NGF. The elevated levels of NGF in SLE and its correlations with the disease activity raise the question of what role NGF plays in that inflammatory disease. Till now, it is not clear whether NGF has a causal role in inflammatory processes or it represents a part of defensive mechanism. Several studies suggest that NGF may be implicated in the development of inflammatory response. NGF has been shown to accumulate at the inflammation site and it is a potent attractant for neutrophils ${ }^{(37)}$. Further, there are reports that administration of neutralizing anti-NGF antibodies can inhibit development of inflammation $^{(38)}$. On the other hand, an anti-inflammatory function was suggested, Bracci-Laudiero et al. ${ }^{(39)}$ reported that NGF is able to protect against autoimmune encephalomyelitis. Moreover, Braccilaudiero et al. ${ }^{(30)}$ found that NGF, through the regulation of calcitonin gene-related peptide (CGRP) synthesis, could down regulate the immune response and the increased levels of NGF might represent a physiological mechanism to dampen the inflammatory response. However, it remains to be studied whether the use of NGF or anti-NGF antibodies may have some beneficial effects during the various stages of that disease.

$I L-13$, a sort of Th2 cytokine cloned recently, is mainly produced by activated $\mathrm{T}$-cells ${ }^{(15)}$. It can stimulate B-cell proliferation and activation and induce Ig secretion, and plays an important role in humoral immune response. Our study found that serum IL-13 levels in active SLE patients were significantly higher than those of inactive SLE patients $(\mathrm{P}<0.01)$, and the inactive patients also had significantly increased IL-13 levels as compared with normal controls $(\mathrm{P}<0.05)$, which were in agreement with the results of Gong et al. ${ }^{(40)}$. These results indicated that abnormal transcriptional levels of IL-13 probably existed in SLE patients. Serum IL-13 levels in inactive patients were significantly higher than those of healthy controls, suggesting lymphocytes of inactive patients might come into being an active state. Kimata et al. ${ }^{(\mathbf{8})}$ reported that NGF increased Ig production and lymphoblastoid Bcell lines proliferation in a dosedependent manner. Meanwhile, Brodie et al. ${ }^{(14)}$, also demonstrated that low-affinity NGF receptors (NGFR) were expressed on human B-lymphocytes, and NGF could regulate the action of $\mathrm{B}$-cell through the specific receptors and then led to B-cell proliferation and Ig production. The present study also, proved that the levels of NGF in active SLE patients were significantly increased. It has been found that NGF can directly stimulate IL-13 secretion in 
immune cells. Furthermore, NGF can also promote the releasing of IL-4 and IL-5 in immune cells and increase the production of $\mathrm{IgE}$ and IgG . These findings suggest that NGF may magnify the action of Th2 cell and increase the releasing of IL-13. In the current study, it was found that the levels of serum IL-13,TNF- $\alpha$ and NGF had a positive correlation. At the same time, it was also observed that there was a close correlation between the levels of serum IL-13 or NGF and activation markers, such as SLEDAI, C3 ,C4 and ESR. These results indicate that NGF affects B-cell together with IL13 and TNF- $\alpha$ to participate in the pathogenesis of SLE.

$T N F-\alpha$ is a $17 \mathrm{kD}$ protein containing 157 amino acids ${ }^{(41)}$. TNF$\alpha$ is produced primarily by activated monocytes/ macrophages, activated $\mathrm{T}$ cells, B cells, mast cells, endothelial cells and fibroblast ${ }^{(42)}$. TNF- $\alpha$ has different effects on the immune cells, it is a growth factor for B lymphocytes $^{(\mathbf{1 6})}$ and, also, it constitutes an activation and maturation factor of dendritic cells which are essential in immune regulation and have, also, been implicated in autoimmunity in general, and SLE in particular ${ }^{(17)}$.

In the current study, significant increases in serum levels of TNF- $\alpha$ were present in SLE patients, but higher levels of serum TNF- $\alpha$ were present in patients with active SLE as compared with patients with inactive SLE. The results of the present study agree with those of Aringer et al. ${ }^{(43)}$, Miret et al. ${ }^{(44)}$ and Studnicka-Benke et al. $^{(45)}$. In their study on Egyptian patients with SLE, Sabry et al. ${ }^{(46)}$ found high levels of TNF- $\alpha$ especially in patients with lupus nephritis.

In contrast to the present findings, Al-Janadi et al. $^{(47)}$ found increased levels of serum TNF- $\alpha$ only in a minority of patients with active SLE that correlated only with thrombocytopenia and these levels were within normal ranges in other clinical presentations .Of particular interest, Gomez et al. ${ }^{(48)}$ found that TNF- $\alpha$ levels were diminished as a function of disease activity, suggesting a possible protective role in SLE. The lack of association between these data and the results of the present study could be explained by the hypothesis that SLE is a genetic disease ${ }^{(49)}$ and it could be assumed that the difference in the genetics of different populations might be responsible for the difference in clinical presentation.

Significant positive correlation was observed between TNF- $\alpha$ and SLEDAI score indicating that TNF- $\alpha$ could be used as a sensitive marker for SLE disease activity. Moreover, a positive correlation was detected between TNF- $\alpha$ and NGF, a finding supports the notion that TNF- $\alpha$ is a potent inducer of NGF production.

In conclusion, NGF, IL-13 and TNF- $\alpha$ are involved in the pathogenesis of SLE and closely correlated with disease activity. The determination of serum NGF, IL-13 and TNF- $\alpha$ levels contribute to evaluating disease activity. These must have some clinical instructive values in designing therapeutic plans and estimating curative effect. On the other hand, inhibitors to NGF, IL-13 and TNF- $\alpha$ may have some beneficial effects in SLE, and 
the medication of them needs to be further studied.

\section{REFERENCES}

1. Funauchi, M.; Ikoma, S.; Enomoto, U. and Horiuchi, A. (1998): Decreased Thl- like and increased Th2- like cells in systemic lupus .erythematosus. Scand. J. Rheumatol., 27: 219224.

2. Wallace, D.J. and Hahn, B.H. (2002): Dubois' lupus erythematosus. Philadelphia: Lippincott Williams and Wilkins.

3. Lauwerys, B.R. and Houssiau, F.A. (2003): Involvement of cytokines in the pathogenesis of SLE. Adv. Exp. Med. Biol., 250: 237-251.

4. Bonini, S.; Rasi, G,; BracciLaudiero, M.L.; Procoli, A., and Aloe, L. (2003): Nerve growth factor: Neurotrophin or cytokine. Int. Arch. Allergy. Immunol., 131: 80-84.

5. Barde, Y.A. (1990): The nerve growth factor family. Prog. Growth Factor Res., 2: 237-248.

6. Thoenen, H.; Bandtlows, C., and Heumann, R. (1987): The physiological function of NGF in the central nervous system: Comparison with the periphery. Rev. physiol. Biochem., 109:145-178.

7. Aloe, L.; Bracci - Laudiero, L.; Bonini, S., and Manni, L. (1997): The expanding role of NDF: From neurotrophic activity to immunologic diseases. Allergy 52: 883-994.

8. Kimata, H.; Yoshida, A.; Ishioka, C.; Kusunoki, T.;
Hosoi, S., and Mikawa, $\mathbf{H}$. (1991): Nerve growth factor specifically induces human IgG4 production. Eur. J. Immunol., 21: 137-141.

9. Brodie, C, and Gelfand, E.W. (1992): Functional nerve growth factor receptors on human Blymphocytes. Interaction with IL2. J. Immunol., 148: 3492-3497.

10. Aloe, L.; Tuveri, M.A.; Carcassi, U., and Levi-Monta Icini, R. (1992): Nerve growth factor in the synovial fluid of patients with chronic arthritis. Arthritis Rheum., 35: 351-355.

11. Tuveri M.A.; Passiu, G.; Mathieu, A.; and Aloe, L. (1993): Nerve growth factor and mast cell distribution in the skin of patients with systemic sclerosis. Clin. Exp. Rheumatol., 11: 319-322.

12. Aalto, K.; Korhonen, L.; Lahdenne, P.; Pelkonen, P., and Lindholm,D. (2002): NGF in serum of children with SLE is correlated with disease activity. Cytokine 20 (3): 136-139.

13. Molnar, I.R and Bokk, A. (2006): Decreased NGF levels in hyperthyroid Graves' ophthalmopathy highlighting the role of neuroprotective factor ; in autoimmune thyroid diseases. Cytokine 35: 109-114.

14. Brodie, C. (1996): Differential effects of Thl and Th2 derived cytokines on NGF synthesis by mouse astrocytes. Fed. Eur. Biochem. Societ. (Letter), 394: 117-120.

15. Liu AH. Allergy and asthma (2000): classic TH2 diseases. Allergy Asthma Proc., 21(4) : 227 
16. Rieckmann, P.; Tuscano, J.M., and Kehrl, J.H. (1997): TNF- $\alpha$ and IL- 6 in B-lymphocyte function, Methods 11: 128-132.

17. Palucka, A.K.; Banchereau, J.; Blanco, $P$. and Pascual, V. (2002): The interplay of dendritic cell subsets in SLE. Immunol. Cell Biol., 80: 484-8.

18. Tutuncu Z., Morgan G.J. Jr, Kavanaugh A. (2002): AntiTNF- $\alpha$ therapy for other inflammatory conditions. Clin Exp Rheumatol., 20: 146- 151.

19. Tan, E.M.; Cohen, A.S.; Fries, J.F.; Mast, A.T.; Meshane, D.J.; Rothfield, N.F.; Schaller, J.G.; Talal, N., and Winchester, R.J. (1982): The 1982 revised criteria for the classification of systemic lupus erythematosus. Arthritis Rheum., 25: 1271-1277.

20. Bombardier, C,; Gladman, D.D.; Urowitz, M.B.; Caron, D., and Chang, CH. (1992): Derivation of the SLEDAI. A disease activity index for lupus patients. The Committee on Prognosis Studies in SLE. Arthritis Rheum., 35: 630-640.

21. Peter, J. B. and Dawkins R. F. L. (1979): Evaluating autoimmune disease. Diagnostic Med., 10: 68- 76.

22. Hebert, L.A.; Cosio, F. G., and Neff, J.C. (1991): Diagnostic significance of hypocomplementemia. Kidney Int., 38: 811- 821.

23. Hellweg, R.; Hock, C., and Hartung, H, D. (1989): An improved rapid and highly sensitive enzyme immunoassay for nerve growth factor. J.
Methods Cell Mol. Biol., 1: 4349.

24. Xu Z., and Chen, Y. (2005): Determination of serum IL-13 and NGF in patients with systemic lupus erythematosus and clinical significance. J. Huazhong. Univ. Sci. Technology Med. Sci., 25 (3): 360-361.

25. Cannon .TG, Nerd, JL, Poutsikad. DD and Dinarello. CA (1993): Measuring circulating cytokines. J.Appl. Physiol., 75:1897-1902

26. Tsokos, G.C. (1999): Overview of cellular immune function in systemic .lupus erythematosus. In: Lahita EG, ed, SLE, 3rd ed. San Diego Academic Press, p. 1754.

27. ToricaTM.; Bracci-Laudiero, L. and Lucibello, M. (1996): NGF is a survival factor for B lymphocytes. Cell 85: 345-356.

28. Aloe, L; Tuveri, M.A. (1997): NGF \& autoimmune rheumatic diseases. Clin. Exp. Rheumatol., 15 (4): 433-441.

29. Dicou, E.: Masson, C.; Jabbour, W., and Nerviere, V. (1993) : increased frequency of NGF in sera of rheumatoid arthritis and systemic lupus erythematosus patients. Neuroreport 5: 321-324.

30. Bracci- Laudiero, L, Aloe, L.; Levi-Montalcini, R.; Buttinelli, C.; Schilter, D.; Gfflessen, S., and Otten, U. (1992): Multiple sclerosis patients express increased levels of beta-nerve growth factor in cerebrospinal fluid. Neurosc. (Letter), 147: 912. 
31. Riikonen, R.S.; Soderstrora, S.; Korhonen, L.T., and Lindholm, D.B. (1998): Over-stimulation of nerve growth factor in postinfectious and autoimmune diseases. Pediatr. Neurol., 18: 231-235.

32. Leon, A.; Buriani, A.; Dal Toso, R.; Fabris, M.; Romanello, S.; Aloe, L., and Levi-Montalcini, R. (1994): Mast cells synthesize, store, and release NGF. Proc. Natl. Acad. Sci. (USA), 91: 3739-3743.

33. Nilsson, G.; Forsberg-Nilsson, K., and Xiang, Z. (1997): Human mast cells express functional TrkA and are a source of nerve growth factor. Eur. J. Immunol., 27: 2295-2301.

34. 34-Hattori, A.; Tanaka, E.; Murase, K.; Ishida, N.; Chatani, Y.; Tsujimoto, M.; Hayashi, K., and Kohno, M. (1993): TNF stimulates the synthesis and secretion of biologically active nerve growth factor in non-neuronal cells. J. Biol. Chem., 268: 2577-2582.

35. Aloe, L.; Probert, L.; Kollias, G.; Bracci-Laudiero, L.; Spillantini, M.G. and LeviMontalcini, R. (1993): The synovium of transgenic arthritis mice expressing human tumor necrosis factor contains a high level of nerve growth factor. Growth Factors 9: 149-155.

36. Bennett, G.; Al-Rashed, S.; Hoult, J.R., and Brain, S.D. (1998): Nerve growth factor induced hyperalgesia in the rat hind paw is dependent on circulating neutrophils. Pain 77: 315-322.
37. Stanisz, A.M., and Stanisz, J.A. (2000): NGF and neuroimmune interactions in inflammatory diseases. Ann. N.Y. Acad. Sci., 917: 268.

38. Villoslada, P.; Hauser, S.L.; Bartke, L; Unger, J.; Heald., N.; Rosenberg, D.; Cheung, S.W.; Mobley, W.C.; Fisher, S., and Genain, C.P. (2000): Human NGF protects common marmosets switching the balance of $\mathrm{T}$ helper cell type 1 and 2 cytokines within the central nervous system. J. Exp. Med., 191: 1799-1806.

39. Bracci-Laudiero, L.; Aloe, L.; Buanne, P.; Finn, A.; Stenfors, C.; Vigneti, E,; Theodorsson, E., and Lundeberg, T. (2002): NGF modulates CGRP synthesis in human B-lymphocytes: a possible anti-inflammatory action of NGF?. J. Neuroimmunol., 123: 58-65.

40. Gong J Q, ChenzQ, HuZJ et al. (2001): Expression of IL- 13 mRNA in the peripheral blood mononuclear cells of the patients with systemic lupus erythematosus. J Clin Dermatol.(Chinese), 30(5) :287

41. Oppenheim, J.J.; Francis, W. and Ruscetti, F.C. (1994): Cytokines. In Immunology. Basic \& Clinical, ed 8. Stites DP, Terr AL, Parslow TG, eds. Appleton \& Lance, pp. 105-23.

42. Elgert, K.D. (1996): Immunology: Understanding the Immune System. New York, Wiley-Liss.

43. Aringer, M.; Zimmermann, C.; Graninger, W.B.; Petera, P.; Steiner, G.; Ulrich, W., and 
Smolen, J.S. (2002): TNF- $\alpha$ is an essential mediator in lupus nephritis. Arthritis Rheum., 46: 3418-9.

44. Miret, C.; Font, J.; Molina, R.; Garcia- Carasco, M.; Filella, X.; Romos, M.; Cervera, R.; Ballesta, A., and Ingelmo, $H$. (2001): Relationship of oncogenes (S. Fas, Bcl-2) and cytokines (IL-10. TNF- $\alpha$ ) with the activity of SLE. Anti cancer Res., 21 (4B): 3053- 9.

45. Studnicka-Benke, A.; Steiner, G.; Petera, P., and Smolen, J.S. (1996): TNF- $\alpha$ and its soluble receptors parallel clinical disease and autoimmune activity in systemic lupus erythematosus. $\mathrm{Br}$. J. Rheumatol., 35: 1067-1074.

46. Sabry, A.; Sheashaa, H.; ELhusseini, A.; Mahmoud, K.; Eldahshan, K.F.; George, S.K.; Abdel-Khalek, E.; ELShafey, E.M.; and AbouZenah, H. (2006):
Proinflammatory cytokines (TNF- $\alpha$ and IL- 6) in Egyptian patients with SLE: Its correlation with disease activity. Cytokine 25: 148-153.

47. Al-Janadi, ML; al-Balla, S.; AlDalaan, A.; and Raziuddin, S. (1993): Cytokine profile in systemic lupus erythematosus, rheumatoid arthritis, and other rheumatic diseases. J. Clin. Immunol., 13: 58-67.

48. Gomez, D.; Correa, P.A., Gomez, L., M.; Cadena, J.; Molina, J.F., and Anaya, J. (2004): Thl/Th 2 cytokines in patients with systemic lupus erythematosus: Is tumor necrosis factor- $\alpha$ protective?. Seminars in Arthritis and Rheumatism 33 (6): 404-413.

49. Kelly, J.A., Moser, K.L., and Harley, J.B. (2002): The genetics of systemic lupus erythematosus: Putting the pieces together. Genes \& Immunity 3 (Suppl.,): S71-S85. 


\section{عامل نمو الأعصاب وانترلوكين بّ اوعامل التنكرز للأورام فى مصل الام

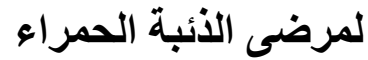

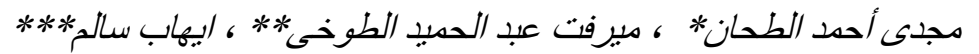

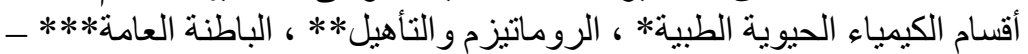

كلية الطب البشرى - جامعة الزقازيق

أجرى هذا البحث فى أقسام الكيمياء الحيوية الطبية ، الروماتيزم والتأهيل ، الباطنة العامة ـ كلية الطب

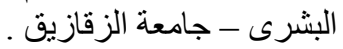

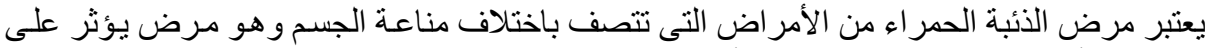

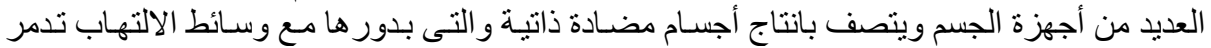

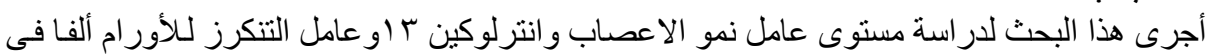

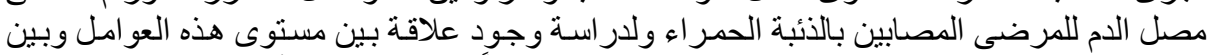

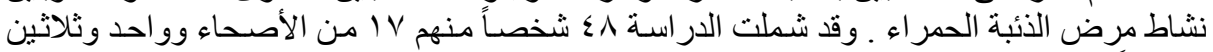

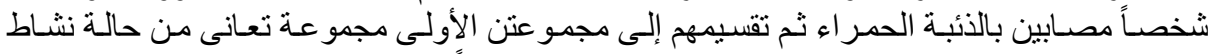

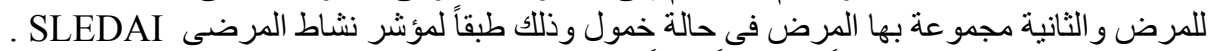

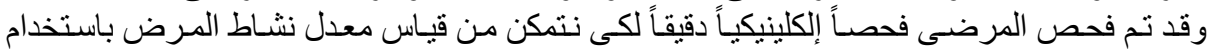

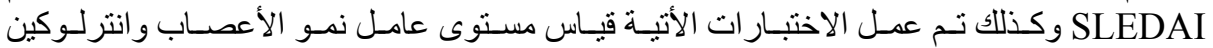

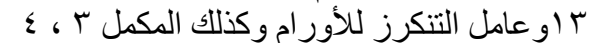

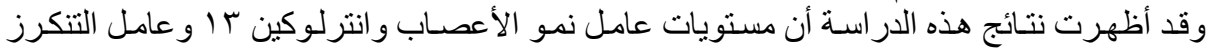

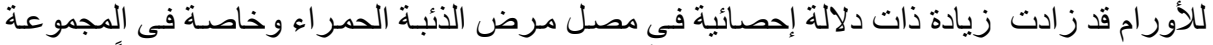

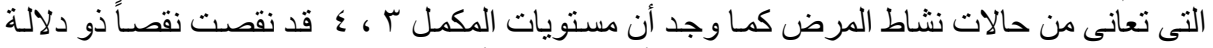

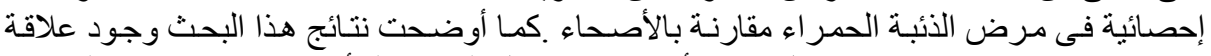

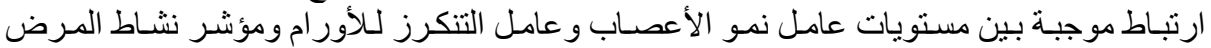

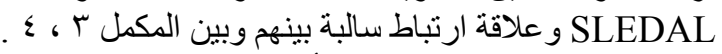

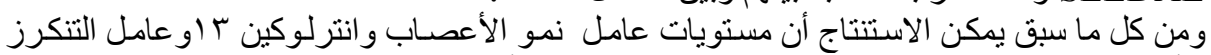

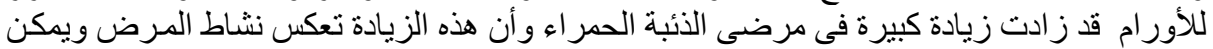
أن تؤخذ كمؤشر ودلالة للحالة المرضية في كرضى 